\title{
Endurreisn Íslands:Hvernig geta fyrirtækin byggt sig upp á ný?
}

\author{
Benedikt Jóhannesson
}

\begin{abstract}
Ágrip
Í ritgerðinni er lýst áhrifum óstöðugs efnahagsumhverfis á rekstur fyrirtækja hér á landi. Höfundur fullyrðir að mikilvægt sé að fyrirtækin búi við stöðugt umhverfi, hafi heilbrigða eiginfjáruppbyggingu, hóflegar skuldir, rúma lausafjárstöðu og heilbrigða stjórnun. Sá sem reki fyrirtæki purfi að vita hver verðbólgan verði í framtíðinni; hversu hátt gengi krónunnar verði; hvert launastigið verði; hversu mikið fyrirtækið skuldi; hver eigi fyrirtækið og hver sé eftirspurn eftir vörum og pjónustu fyrirtækisins. Í raun hafi stjórnendur fyrirtækja ekki kunnað svörin við pessum spurningum á síðustu árum og enginn viti hvernig framtíðin verði. Stór hluti fyrirtækja sé með neikvætt eigið fé vegna gengisfalls krónunnar og bankar séu fyrst og fremst fjárfestingabankar sem gæti eigin hagsmuna fremur en viðskiptavina sinna. Dæmi séu um að bankarnir eigi félög að fullu og hafi rekið sjálfir í á annað ár. Höfundur leggur til aðgerðalista sem felur í sér hallalaus fjárlög 2012; markvissa stefnu um að minnka opinberar skuldir niður fyrir $60 \%$ af VLF á fimm árum; að kauphækkanir verði litlar; gjaldeyrishöft verði afnumin; lokið við samninga við Evrópusambandið og mörkuð stefna um að leggja krónuna af.
\end{abstract}

\begin{abstract}
The author describes the effect of economic instability on businesses in Iceland. He writes that it is important that firms operate in a stable economic environment, have a healthy capital base, moderate leverage, ample liquidity and a cautious management style. Management must be able to predict future inflation; to predict future exchange rates; to predict wage developments; to be able to assess the current level of leverage; to know who owns the firm; and to predict the demand for its goods and services. The author claims that managers of Icelandic firms have not been able to answer these questions accurately in the past few years and no one can predict the future at this point in time. A large fraction of businesses are insolvent because of the currency depreciation and the country's commercial banks are in fact investment banks which guard their own interests much more than the interest of their customers. The banks own many businesses fully and have operated some of them for almost two years. The author proposes that the government deficit be eliminated by 2012; that public debt be lowered to $60 \%$ of GDP in five years time; that wage increases should be moderate; capital controls abolished; a membership treaty be negotiated with the $\mathrm{EU}$; and a plan be made to abolish the krona.
\end{abstract}

JEL flokkun: M21

Lykilhugtök: Endurskipulagning skulda, Efnahagsumhverfi fyrirtækja 


\section{Inngangur}

Pó að nú séu liðnir 20 mánuðir frá hruninu fer pví fjarri að endurskipulagningu fjármálalífsins sé lokið. Margir virðast ráðprota pegar kemur að pví að höggva á hnúta. Lykillinn að lausn liggur hjá bönkunum en par er víða pottur brotinn. Vinnubrögð peirra eru ekki samræmd og fjarri pví að vera gagnsæ. Hér á eftir verður farið yfir vandann sem enn blasir við, umhverfið sem fyrirtækin purfa á að halda og leiðina að pví marki. Áður en lengra er haldið er pó vert að víkja að pví hvenær Ísland fór út af sporinu.

раð er vinsælt og eðlilegt að Íslendingar beri sig saman við nágrannapjóðir. Peirra menning er lík okkar og pví eðlilegt að bera saman lífskjör hérlendis og á peim svæðum. Hagvöxtur ætti að vera svipaður hér á landi og í pessum löndum ef svipuðum hagstjórnaraðferðum er beitt og landshagir eru sambærilegir.

Á undanförnum 30 árum hefur verg landsframleiðsla (VLF) á mann prefaldast á Íslandi. Pað er ekki svo lítið og pví ekki að undra að lífskjör séu góð. Á sama tíma hefur VLF hins vegar nær fjórfaldast á peim svæðum sem við berum okkur helst saman við. Á Mynd 1 sést próunin á tímabilinu frá 1980-2008. Síðan pá má ætla að próunin hafi verið svipuð hér á landi og á samanburðarsvæðunum. Nú síðast var sagt frá pví að á fyrsta ársfjórðungi hefði VLF á Íslandi aukist um 0,3\% frá fyrra ári. Рað voru góð tíðindi. En hvers vegna gengur Íslendingum verr en öðrum að stjórna hagkerfinu?

\section{Prjú samdráttarskeið}

Frá 1980-1987 gekk álíka vel á Íslandi og á samanburðarsvæðinu en árið 1988 skall fyrsta kreppan á vegna aflabrests og offjárfestingar í sjávarútvegi. Við inngönguna í Evrópska efnahagssvæðið árið 1993 fór hagurinn að vænkast á ný. Próunin síðan pá er sýnd á Mynd 2. Hér var stöðugleiki fram yfir aldamót. Pá misstu Íslendingar stjórn á gengi krónunnar rétt einu sinni. Ástæðan var meðal annars launahækkanir umfram raunverulega verðmætaaukningu. Úr peirri kreppu rættist einnig og hagur landsmanna vænkaðist á ný. Árið 2006 fór enn að syrta í álinn og góðærið mikla 2007 var allt fengið að láni.

Раð vekur athygli pegar myndir 1 og 2 eru skoðaðar að samanburðarsvæðin eru nær stöðugt í vexti meðan Îsland virðist hiksta á nokkurra ára fresti. Skýringin er sú að hér á landi er allt rekstrarumhverfið miklu óstöðugra en erlendis. Sveiflur í verðbólgu, vöxtum og gengi krónunnar valda pví að Ísland dregst smám saman aftur úr. Eina ástæðan fyrir pví að ekki er sýnilegt að lífskjör eru lakari á Íslandi en annars staðar er að Íslendingar tóku mikil lán. Pannig hefur peim tekist að halda sjó á yfirborðinu. Рað tekst hins vegar ekki lengur pegar að skuldadögum kemur. Á næstu áratugum parf pjóðin að greiða lánin niður og pá verður munurinn ljós.

Hver ber ábyrgðina á pví að pjóðin hefur dregist aftur úr? Pví er auðsvarað. Stjórnmálamenn sem hafa viljað halda Íslandi utan við umheiminn og alpjóðlegt umhverfi. Par hafa pó verið tekin gæfuspor. Inngangan í EFTA árið 1970 og á EES-svæðið tæpum aldarfjórðungi síðar bætti lífskjör pjóðarinnar mikið ella væri vöxtur hagkerfisins nú eflaust ekki nema liðlega hálfdrættingur á við pað sem gerist í samanburðarlöndum. Í stað pess hefur hann aukist um 20\% minna en par á 28 árum. Рað pýðir að meðaltali tæplega 1\% á ári. Með pessu áframhaldi er landið dæmt til pess að verða annars flokks pegar til langs tíma er litið. 


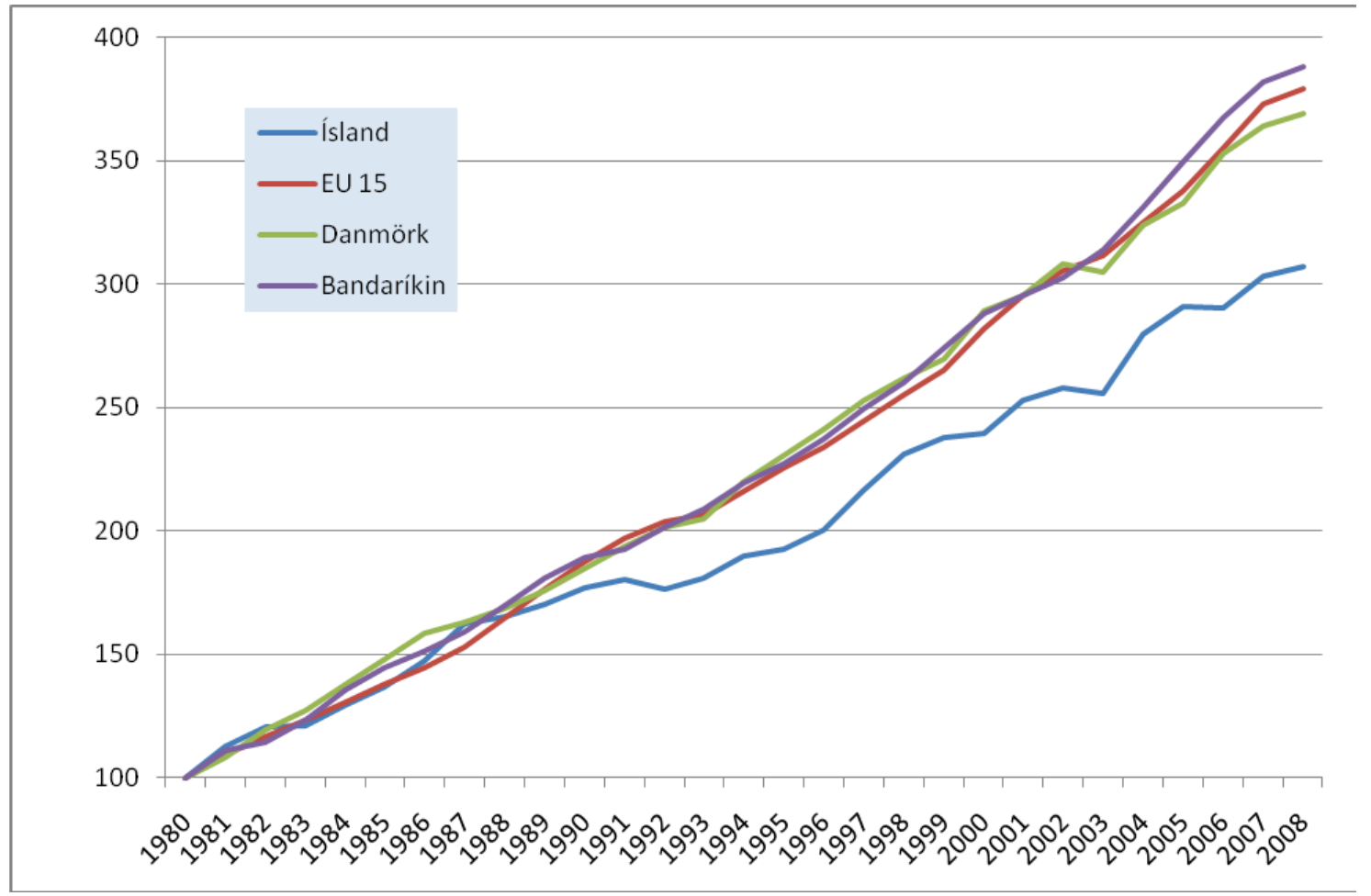

Mynd 1:Verg landsframleiðsla á mann 1980-2008

(Purchasing Power Parity, PPP, vísitala, 1980=100)

Heimild: Fyrirlestur dr. Gísla Hjálmtýssonar, Framtíðarsýn fyrir Îsland, fluttur vorið 2010 hjá Sterkara Íslandi.

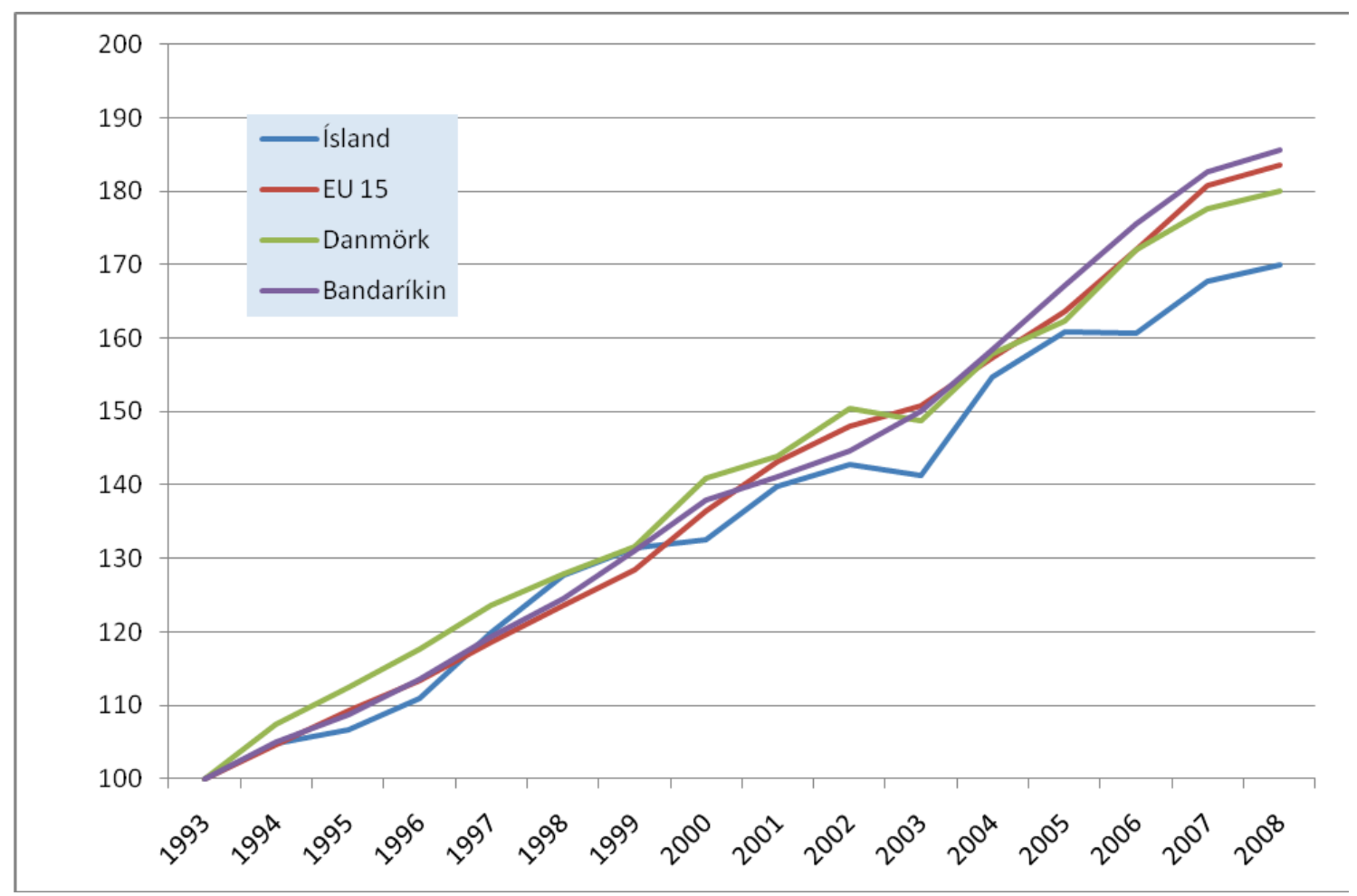

Mynd 2: Verg landsframleiðslu á mann 1993-2008

(Purchasing Power Parity, PPP, vísitala, 1993=100)

Heimild: Fyrirlestur dr. Gísla Hjálmtýssonar, Framtíðarsýn fyrir Ísland, fluttur vorið 2010 hjá Sterkara Íslandi. 


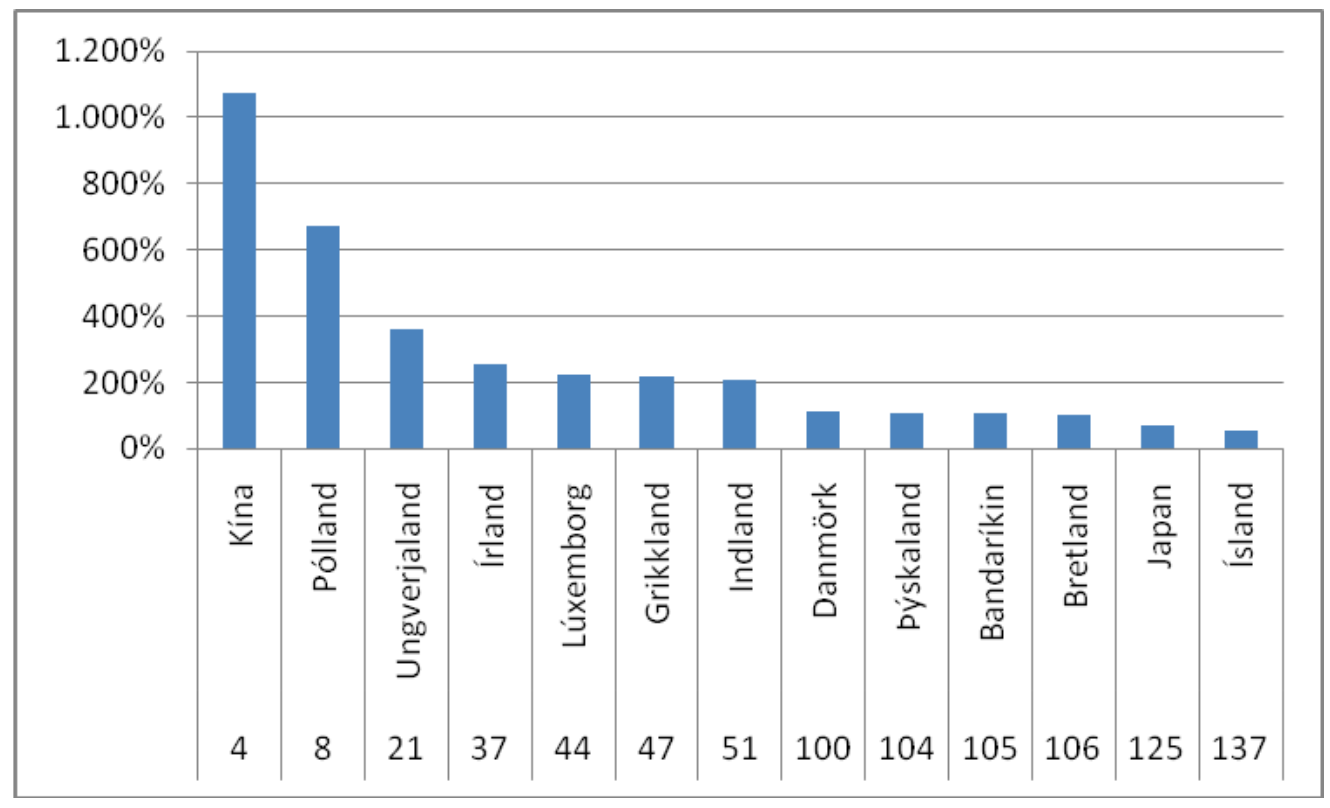

Mynd 3. Vöxtur VLF á mann frá 1990 til 2010.

Áætluð VLF 2010 reiknuð í Bandaríkjadölum. Heimild: EconStats.com.

Staðan er enn verri ef horft er til samtímans og VLF á mann, reiknuð í Bandaríkjadölum, er skoðuð. Undanfarin 20 ár hefur VLF á mann tvöfaldast í Bandaríkjunum. Í einstaka ríkjum eins og Kína hefur hún stökkbreyst (sjá mynd 3). Mörgum Evrópuríkjum hefur vegnað miklu betur en Bandaríkjunum. Nefna má ríki Austur-Evrópu en einnig Írland, Lúxemborg og Holland. Í öllum pessum ríkjum hefur VLF á mann 2,5 til 3,5 faldast á pessu tímabili. Spánn, Kýpur og Grikkland eru líka með meiri hagvöxt á mann en Bandaríkin. Á pessu tímabili var hagvöxtur á mann í Bretlandi og Pýskalandi nákvæmlega sá sami og í Bandaríkjunum. Á milli Egyptalands og Papúa Nýju-Gíneu má hins vegar finna Ísland sem náði ekki að vaxa nema um 56\% á pessum tíma. Ekkert Vestur-Evrópuríki er neðar á listanum. Af pessu er ljóst að Íslendingum hefur miðað aftur á bak miðað við öll pau lönd sem við höfum viljað bera okkur saman við undanfarna áratugi.

\section{Hvað purfa fyrirtækin?}

Margir hafa spurt sig hvert sé markmið fyrirtækja í kreppunni? Einfalda svarið er að sjálfsögðu pað að lifa hana af. En hvernig tekst peim pað og hvað svo? Reyndar hafa pau grundvallarsannindi sem gilda um fyrirtæki í rekstri ekkert breyst. Mikilvægustu atriðin eru:

- Stöðugt umhverfi.

- Heilbrigð eiginfjáruppbygging.

- Hóflegar skuldir.

- Rúm lausafjárstaða.

- Heilbrigð stjórnun.

Allt kallar petta á heilbrigt fjármálalíf sem pýðir að bankastarfsemin parf að vera eðlileg. Á pað skortir mikið á Íslandi eins og vikið verður að hér á eftir. Í sjálfu sér er pað að sumu leyti athyglisvert að allt purfi að umturnast til pess að menn átti sig á pví að gömlu gildin voru í raun og veru rétt. Hagfræðingar vitna stundum í Joseph Schumpeter sem setti fram kenninguna um skapandi eyðileggingu (e: creative distruction) par sem ný og betri veröld er 
reist á rústum hinnar fyrri. Oftast verður bylting Schumpeters reyndar ekki með peim hætti að heilt hagkerfi hrynji heldur kemur ný tækni í stað gamallar eða ný félög ýta út fyrirtækjum sem áður áttu markaðinn. Á Íslandi má segja að eyðileggingin hafi staðfest pað sem menn gátu áður vitað um sjúkt hagkerfi par sem fyrirtæki skulduðu allt of mikið, eiginfjárhlutfall var of lágt og verðmat á fyrirtækjum of hátt.

\section{Veikleikar hagstjórnar}

Seðlabankanum mistókst að viðhalda stöðugleika fjármálakerfisins. En hvað fór úrskeiðis? Í stuttu máli má segja að pað sem fór úrskeiðis var að fyrirtæki, bankar og einstaklingar notfærðu sér vaxtamuninn á milli Íslands og helstu viðskiptalanda til pess að hagnast án pess að taka nægilegt tillit til væntanlegrar gengislækkunar krónunnar. Með pví að taka lán í lágvaxtamynt og endurlána í hávaxtamynt er unnt að búa til bókhaldslegan hagnað í fyrirtækjum og einstaklingar geta bætt stöðu sína til skamms tíma með gengistryggðum lágvaxtalánum. Pannig myndast ágóði til skamms tíma en gengisfall krónunnar verður síðar til pess að pessir aðilar verða gjaldprota. ${ }^{1}$ Segja má að stór hluti fyrirtækja, banka og heimila hafi á einn eða annan hátt tekið pátt í vaxtamunarviðskiptum. ${ }^{2}$ Afleiðingarnar urðu margvíslegar:

- Hærri vextir Seðlabanka Íslands höfðu lítil sem engin bein áhrif á einkaneyslu og fjárfestingu vegna pess að porri lána heimila er verðtryggður á föstum vöxtum til mjög langs tíma og fyrirtækin viku sér undan lánunum með pví að taka gengistryggð lán.

- Verðbólgumarkmið varð til pess að Seðlabankinn tók að nota vaxtastefnuna til pess að koma í veg fyrir gengisfall krónunnar vegna verðbólgumarkmiðsins og áhrifa á efnahagsreikninga fyrirtækja og heimila. Petta olli pví að fleiri tóku að nýta sér vaxtamun með gengistryggðum lánum eða öðrum vaxtamunarviðskiptum.

- Útlánum bankanna var leyft að vaxa um yfir 50\% á ári. Útlán til fyrirtækja jukust mest en einnig útlán til heimila. Samtímis jókst peningamagn (M3) mikið.

- Bönkunum var leyft að stækka efnahagsreikning sinn pannig að hann fimmfaldaðist á aðeins fjórum árum.

- Ríkisútgjöld jukust og skattar lækkuðu sem dró úr áhrifum sjálfvirkrar sveiflujöfnunar ríkissjóðs. Pannig varð fjármálastjórn ríkisins ekki til pess að styðja við peningamálastjórnina. Segja má að ríkið hafi tekið til sín hluta af hagnaði vaxtamunarviðskiptanna og eytt honum án pess að leggja til hliðar til pess tíma pegar pau gengju aftur.

- Miklir brestir urðu á regluverki og eftirliti með fjármálastofnunum, eins og lýst er í skýrslu Rannsóknarnefndar Alpingis, einkum er varðar lán til eigenda og aðgerðir banka til pess að auka eigið fé bankanna með lánum til hlutabréfakaupa.

Við pennan lista verður síðan að bæta að miklir eftirspurnarskellir dundu á íslenska hagkerfinu á árunum 2003-2007, svo sem stóriðjufjárfestingar á Austurlandi og

1 Arnór Sighvatsson (2007) lýsir erfiðleikum peningamálastjórnunar pegar fjármagn er hreyfanlegt á milli landa og seðlabanki er á verðbólgumarkmiði.

2 Akerlof og Romer (1994) lýsa pví hvernig vaxtamunur á milli landa gerir eigendum fyrirtækja kleift að búa til bókhaldshagnað sem síðan er unnt að nota til pess að réttlæta arðgreiðslur til eigenda sem tæma fyrirtækin og bankana innan frá. 
kerfisbreytingar á húsnæðismarkaði eins og lýst er í nýlegri ritgerð Ásgeirs Daníelssonar (2010).

\section{$5 \quad$ Hvað felst í stöðugu umhverfi?}

Раð er erfitt að komast milli áfangastaða ef menn vita ekki hvar vegurinn er. Vissulega er hægt að troða vegleysur en pær eru bæði seinfarnar og yfirferðin veldur skemmdum. Pess vegna purfa stjórnendur fyrirtækja að hafa fast land undir fótum. Pessa dagana er vinsælt hér á landi að halda fram kenningum um að ekkert henti Íslendingum jafnvel og sveiflukennt umhverfi krónunnar með tilheyrandi verðbólgusveiflum. Petta er fjarri sanni. Pvert á móti purfa fyrirtæki sem vilja vera samkeppnishæf við útlönd að búa við svipað rekstrarumhverfi og erlendir keppinautar. Раð pýðir að peir sem reka fyrirtækin verða að vita nokkurn veginn svörin við eftirfarandi spurningum:

- Hver verður verðbólgan?

- Hvert verður gengi krónunnar?

- Hver verða laun?

- Hvað skuldar fyrirtækið mikið?

- Hver á fyrirtækið?

- Hvernig verða bankaviðskipti fyrirtækisins?

- Hver er eftirspurn eftir vöru og pjónustu fyrirtækisins?

Fæst af pessu vissu íslenskir stjórnendur í upphafi áranna 2008 og 2009. Sumt hefur komið í ljós síðan en annað ekki. Enginn getur sagt með vissu hvernig rekstrarumhverfið verður eftir tvö ár eða prjú. Jafnvel í peim löndum sem verst eru leikin eftir kreppuna á meginlandi Evrópu liggja flest svörin ljós fyrir.

Spár um verðbólguna benda til pess að hún gæti farið undir markmið Seðlabankans í byrjun árs 2011. Óvissan er pó gífurleg vegna haftanna en enginn veit hvenær peim verður aflétt og paðan af síður hvaða afleiðingar pað mun hafa. Fjármagnseigendur hafa ekki aðeins vantraust á krónunni heldur ekki síður á bönkunum og stjórnvöldum. Óttinn við annað bankahrun og aukna skattheimtu gæti leitt til fjármagnsflótta úr landi pegar hagkerfið má síst við pví.

Sumir hafa sagt að lækkandi gengi evrunnar síðastliðið vor hafi sýnt að víðar séu gjaldeyrisvandræði en á Íslandi. Petta er vissulega rétt en pau skipta hins vegar mun minna máli ef stór hluti viðskipta pjóðanna er innan svæðisins. Pess vegna kippa fæstir Bandaríkjamenn eða íbúar evrusvæðisins sér upp við gjaldeyrissveiflur. Pær hafa miklu minni áhrif á verðlag par en gerist á Íslandi.

Margir hafa lýst vanpóknun á tillögunum um launafrystingu í prjú ár sem páverandi félagsmálaráðherra lagði til vorið 2010. Eflaust ganga pær illa upp en pað er mikilvægt að laun verði stöðug í nokkur ár. Í núverandi ástandi er ekki grundvöllur fyrir pví að hækka laun almennt pví að afkoma fyrirtækja og hins opinbera býður ekki upp á kjarabætur. Launahækkanir við slíkar aðstæður leiða aðeins til verðbólgu eða atvinnuleysis. Hins vegar eru kröfur launpega um tryggingu kaupmáttar með tengingu við evru skiljanlegar. Pær gætu pó orðið erfiðar í framkvæmd hjá peim fyrirtækjum sem aðeins hafa tekjur í íslenskum krónum. Eina leiðin til pess að tryggja að slíkt kerfi gangi upp væri að skipta um mynt í öllu hagkerfinu. 
Sú undarlega staða er komin upp á Íslandi að vegna pess að skuldir stórhækkuðu og eignir féllu í verði í hruninu glötuðu fjölmörg fyrirtæki öllu eiginfé sínu. Pau hafa síðan átt í samningaviðræðum við lánardrottna um uppgjör skulda. Sumir bankanna (Íslandsbanki og Landsbanki) hafa boðið upp á lækkun höfuðstóls erlendra lána gegn pví að lánin verði færð yfir í íslenskar krónur á hærri vöxtum. Petta bætir eiginfjárstöðu margra en pó ekki rekstrarstöðuna pví að miðað er við að vextir á innlendum lánum séu mun hærri en á peim erlendu. Auk pess hefur eigendum sumra fyrirtækja verið boðið að kaupa nýtt hlutafé og fá á móti lækkun skulda. Pessi aðgerð veldur pví að eignarhlutföll raskast í mörgum tilvikum. Pessu til viðbótar hafa bankarnir í einhverjum tilvikum viljað breyta skuldum í eiginfjárframlag. Petta virðist meðal annars gert vegna pess að bankarnir sætta sig ekki við pað verð sem fæst fyrir fyrirtækin núna.

Dæmi eru um að bankarnir eigi félög að fullu og hafi rekið sjálfir í á annað ár. Рað er mjög óheppilegt svo ekki sé meira sagt. Bankarnir eru í eigu ríkisins og kröfuhafa. Kröfuhafalistinn virðist síkvikur og ekki liggur fyrir yfirlit um hverjir kröfuhafarnir eru. Allt leiðir petta til pess að markaðurinn er ekki gagnsær. Eitt af pví sem allir eru sammála um að hafi valdið vandræðum á Íslandi er leyndarhjúpur yfir pví hver átti fyrirtækin. Ástandið nú er engu betra.

Krónan síflöktandi er mikill óvinur peirra sem vilja stunda rekstur á Íslandi. Fyrirtæki á innanlandsmarkaði (og neytendur) kveinka sér pegar hún er veik pví að pá eru erlendar vörur dýrar. Styrkist hún hins vegar óhóflega mikið verður hún útflytjendum fjötur um fót. Sem fljótandi rekald á frjálsum markaði er hún uppspretta óstöðugleika, í höftum hamlar hún milliríkjaviðskiptum og erlendri fjárfestingu.

\section{Bankarnir eru ekki heilbrigðir}

Sem fyrr segir er traust bankakerfi ein af forsendum fyrir heilbrigðu efnahagslífi, meðal annars afnámi gjaldeyrishafta. Haustið 2010 skortir mikið upp á að slíkt kerfi sé til á Íslandi . Engan parf að undra að óvissa hafi ríkt um bankana eftir að peir fóru allir í prot í október 2008 og drógu pjóðarbúið með sér. Langt fram eftir árinu 2009 var hvorki búið að setja upp efnahagsreikning peirra né ganga frá eignarhaldi. Рað hefur nú breyst pó að eignarhaldið sé enn óljóst eins og áður er að vikið. Lengi vel var Íslandsbanki eini endurreisti bankinn sem kominn var með bankastjóra til frambúðar. Starf bankanna virðist bera pess merki að ekki var búið að marka stefnu til framtíðar. Líklega eru fá störf jafnmikilvæg á Íslandi núna og störf bankastjóra. Pví skiptir miklu máli að par sé toppfólk sem áttar sig á pví hve mikilvægu hlutverki bankarnir gegna við framtíðaruppbyggingu pjóðfélagsins.

Að undanförnu hefur sá bragur verið á störfum bankanna að peir hafa breyst úr pjónustustofnunum við sína viðskiptavini í innheimtustofnanir fyrir erlend fyrirtæki. Jafnframt hafa peir ólmir viljað eignast fyrirtæki, að hluta eða öllu leyti. petta er afar hættuleg próun. Sem fyrr segir hefur Íslandsbanki markað sér nokkra sérstöðu. Hann hefur lýst pví yfir að hann hafi ekki áhuga á pví að eignast hlut í fyrirtæki (en hefur reyndar ekki alveg staðið við pað) og eignist hann slíkan hlut er pað yfirlýst stefna bankans að selja hann sem fyrst.

Líklega var helsta undirrót hrunsins sú að bankarnir ákváðu að eignast hlut í mörgum stærstu fyrirtækjum landsins. Prátt fyrir ítrekaðar viðvaranir hafa stjórnmálamenn hikað við að banna pað að starfsemi viðskiptabanka og fjárfestingabanka sé undir sama paki. Peir sem leggja fé sitt inn á banka eru áhættufælnastir allra fjármagnseigenda. Stjórnendur fjárfestingabanka eru peir áhættusæknustu. Nú pegar er farið að bera aftur á peirri áráttu 


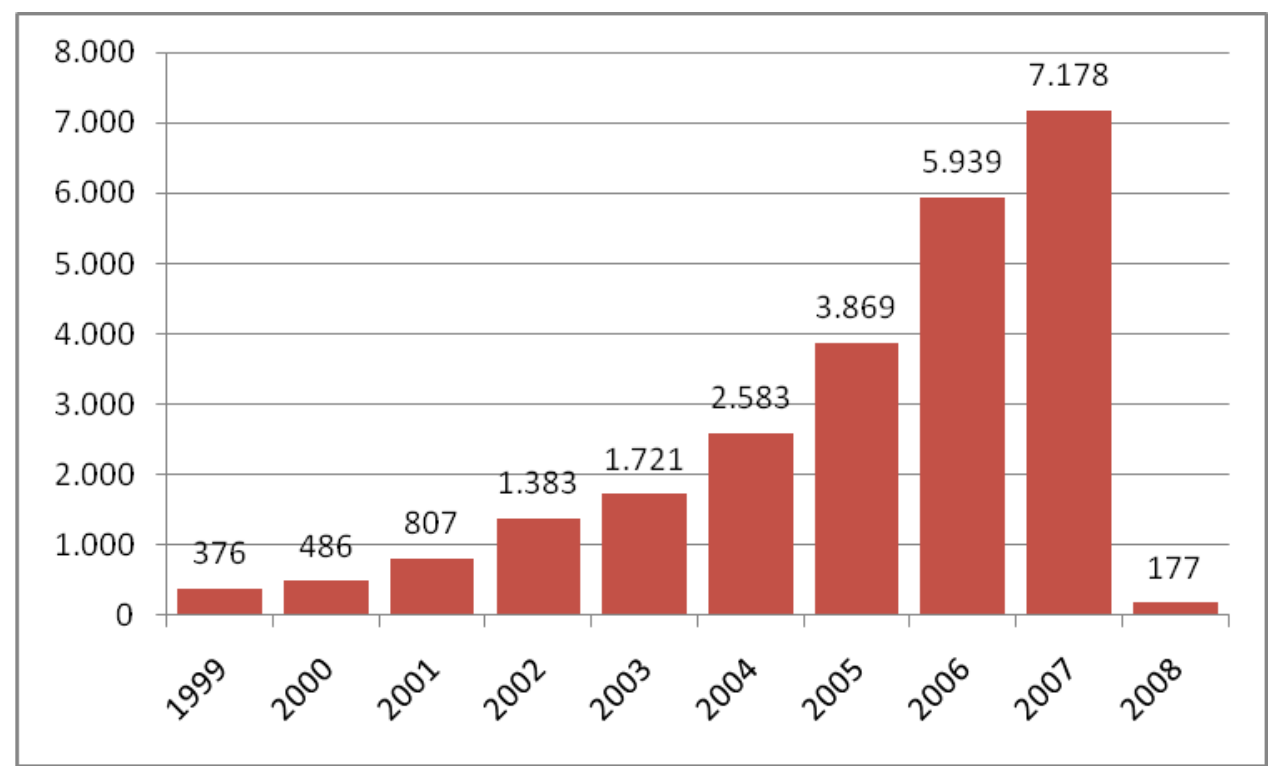

Mynd 4. Eigið fé fyrirtækja 1999 til 2008 skv. skattframtölum (fjárhæðir í milljörðum króna)

Heimild: Páll Kolbeins: Álagning fyrirtækja, Tíund, maí 2010. Útg. Ríkisskattstjóri.

bankamanna að tilgangur bankastarfsemi sé að búa til póknanir fyrir bankana. Markmið peirra er pví ekki að hjálpa viðskiptavinum heldur að búa til „díla“ rétt eins og í gósentíðinni fram til ársins 2007. Petta gæti ekki gerst ef pessi ólíka starfsemi væri aðskilin með lögum. раð er jafnhlægilegt og áður að tala um Kínamúra. Allir vita að slíkir múrar héldu aldrei og pað hefur örugglega ekki breyst. Stjórnendur sátu alltaf klofvega á múrunum og gáfu fyrirskipanir í báðar áttir.

\section{$7 \quad$ Sterkt eiginfé - Hvaðan kemur pað?}

Vegna peirrar óvissu sem ríkir á markaðinum pora fáir innlendir aðilar að leggja fram eiginfjárframlag. Ein ástæðan er sú að bankarnir tregðast við að horfast í augu við raunverulega tapaðar kröfur. Pess vegna eru fyrirtækin of skuldsett fyrir núverandi rekstur en mörg fyrirtæki bera enn skuldir af rekstri sem hefur verið hætt, innan lands og utan. Fyrir utan niðurfærslu á erlendum skuldum, eins og talað var um hér að framan, hafa bankar ekki hrundið af stað neinum almennum, gagnsæjum aðgerðum. Pví er hætta á mismunun í uppgjöri milli fyrirtækja. Ein skýrasta birtingarmynd hrunsins kemur frá ríkisskattstjóra (Mynd 4). Myndin sýnir að a.m.k. sjö milljarðar króna hafa horfið úr eignasafni landsmanna. Ekki parf að efast um að árin 2006 og 2007 hefur eigið fé fyrirtækjanna verið nokkuð bólgið og eignaverð örugglega ofmetið. Pekkt bóluáhrif komu fram og jafnframt hafa verið nefnd dæmi um pað að verðmæti fyrirtækja væri stórlega ofmetið í viðskiptum í blekkingarskyni. Viðskipti með danska flugfélagið Sterling er pekkt dæmi um slíkt.

Ekki parf að efast um að lífeyrissjóðir hafa áhuga á að taka pátt í uppbyggingu á arðbærum fyrirtækjum. Peir eiga mikið fé óbundið og pví væri örugglega betur varið til eiginfjáruppbyggingar í atvinnurekstri en í ýmis gæluverkefni stjórnmálamanna. Peir koma hins vegar ekki að borðinu fyrr en ljóst er að skuldauppgjöri sé lokið. Pess vegna liggur á að bankarnir ljúki sinni vinnu.

Erlendir fjárfestar hafa mikinn hug á að koma til Íslands. Peim hrýs hins vegar hugur við stórveldadraumum bankanna (e: empire building) og segja pá vera áskrift að ógöngum í 
framtíðinni. Раð parf reyndar enginn að efast um pví að hremmingar pjóðarinnar hófust einmitt pegar bankarnir vildu gína yfir öllu. Hér reynir pví mikið á hina nýju bankastjóra og að peir átti sig á pví að bankarnir eru hluti af samfélaginu en ekki öfugt.

Neikvætt viðhorf stjórnvalda, og að hluta til almennings, til útlendinga sem koma hingað með peninga veldur pví að margir peirra hika við fjárfestingar. Annar stjórnarflokkurinn virðist snúast gegn flestum nýjum hugmyndum um verðmætauppbyggingu ef útlendingar koma par nálægt. Aðgerðaleysi stjórnvalda veldur pví að margir óttast annað hrun. Раð virðist ekki líklegt en vantraust á stjórnmálamönnum verður til pess að lítið gerist. Traust verður ekki byggt upp aftur á skömmum tíma og stjórnmálamenn virðast fæstir gera nokkuð til pess að skapa virðingu fyrir sínum störfum.

Til lengri tíma purfa fyrirtæki að eiga nægt eiginfé en lausafjárvandi er engu að síður pað sem getur drepið pau, jafnvel pó að eiginfjárstaðan sé góð. Petta er sambærilegt við pað að milljónamæringur færist úr hungri vegna pess að hann týndi veskinu. Bankarnir hafa mikilvægu hlutverki að gegna við að létta undir með fyrirtækjum sem eiga við tímabundin lausafjárvandræði að etja. Laust fé er eins og smurolía í rekstri. Afar mikilvægt er að bankarnir noti ekki lausfjárvandann til pess að klekkja á fyrirtækjum. Рað er reyndar furðulegt að upp sé komin sú staða að fyrirtækin og bankarnir séu hætt að standa saman um lausn á erfiðleikunum og bankinn sé sjálfur orðinn hluti vandans.

\section{Góð stjórn}

Eitt af pví sem óhjákvæmilega kemur alltaf til tals eftir að allt siglir í strand, líkt og gerðist á Íslandi, er að stjórnir hafi brugðist. Stjórnarhættir koma til endurskoðunar og allt byggist á pví að nýjum og betri reglum sé fylgt. Auðvitað er pað ágætt en meginatriðið er pó að í stjórn séu menn sem hafa vit á rekstrinum, eru heiðarlegir en ekki svo heilagir að peir geti ekki tekið ákvarðanir um nokkurt mál af ótta við að ákvörðunin verði umdeild. Stjórnun er alltaf jafnvægislist milli pess vera praktískur og fylgja formi. Stjórnir purfa að vera formlegar og fylgja parf ákveðnum viðmiðum en meginatriðið er pó að stjórnarmenn reyni að beita heilbrigðri skynsemi. Óhóf og áhættufíkn eiga illa við pegar menn leggja miklu meira undir en peir geta tapað sjálfir, hvað pá pegar allt pjóðfélagið er lagt undir.

Í kreppu hafa aðeins önnur atriði forgang en venjulega. Fyrirtæki purfa að gæta pess að lenda ekki í lausafjárpröng pví að bankarnir hafa verið tregir til pess að veita yfirdráttarlán. Ekki tjóir að bíða eftir batanum handan við hornið. Раð parf að draga úr kostnaði og jafnvel hætta rekstri eininga sem ekki skila afgangi. Рó að sárt sé að horfa á eftir starfsemi sem hefur skilað góðum afgangi gegnum tíðina er рað staðreynd að auðveldara er að byggja upp aftur en að halda taprekstri áfram árum saman. аð vill einnig oft gleymast að pað parf líka að hagræða í peim einingum sem skila afgangi. Hver veit nema par sé mesta fitan?

\section{Páttur ríkisins}

Sagt var á sínum tíma að óhamingju Íslands yrði allt að vopni og pað hefur sannarlega ræst á síðustu árum. Pjóðin purfti leiðsögn pegar efnahagslífið stefndi fram af hengifluginu. Pess í stað voru flestir ráðamenn pjóðarinnar í besta falli pöglir yfir pví sem gerðist og í mörgum tilvikum virkir pátttakendur í atburðarásinni.

- Opna parf hagkerfið fyrir erlendri fjárfestingu. 
- Fylgja lögum og ekki breyta reglum í miðjum leik.

- Eyða óvissu um Icesave.

- Setja fram áætlun um samræmdar aðgerðir - ekki sérlausnir.

- Draga saman í ríkisrekstri og flytja vandann ekki til atvinnulífsins.

- Pjóðarsátt um endurreisn.

Útlendingar vilja margir festa fé á Íslandi. Pað er skiljanlegt af ýmsum ástæðum. Gengi krónunnar er lágt. Peir geta í sumum tilvikum keypt krónur á aflandsmarkaði og fengið pær á enn betra verði en opinbert gengi segir til um. Sumir hafa reiðst yfir pessu en petta er óhjákvæmileg afleiðing haftanna. Pá verður til tvöfalt gengi alveg eins og áður fyrr.

Ítrekaðar deilur um erlenda fjárfestingu draga úr trúverðugleika Íslands. Samningurinn við Verne Holding var mjög lengi að komast í gegnum Alpingi vegna pess að Björgólfur Thor var einn eigenda félagsins. Pjóðin er vissulega vön pví að ekki búi allir við sömu reglur. Á sínum tíma var ráđandi hlutur í Landsbankanum seldur lægstbjóðanda. Verðið var svo lækkað eftirá.

Kanadíska félagið Magma Energy virðist hafa lagt sig í líma við að fylgja íslenskum lögum um fjárfestingu á Íslandi út í ystu æsar. Рað er kallað sýndargjörningur og alpingismenn fara ókvæðisorðum um fyrirtækið.

Hrun krónunnar og bankakerfisins olli slíkum forsendubresti á lánamarkaði að engin dæmi eru um slíkt í Íslandssögunni. Verðmæti eigna minnkaði, lífeyrissjóðir rýrnuðu, laun lækkuðu og minna varð um atvinnu. Á sama tíma hækkuðu skuldir óheyrilega, sérstaklega erlend lán. Dómur Hæstaréttar um erlend lán breytir miklu fyrir ýmsa en ekki eru öll kurl komin til grafar enn. Vísitölubundin lán hækkuðu líka mikið en að öllum líkindum mun pað áfall jafna sig betur pegar til lengri tíma er litið. Pví miður hafa stjórnvöld ekki samræmt stefnu vegna uppgjörs lána. Pess vegna fá peir sem skiptu við einn banka í mörgum tilvikum betri afgreiðslu en peir sem skiptu við annan, pvert á yfirlýsingar um jafnan rétt.

Margir stjórnmálamenn virðast halda að með pví að tala ekki um Icesave-málið hverfi pað. Íslendingar verða að setja málið í einhvern farveg pannig að hér sé ekki óvissa um skuldbindingar Íslands um langa framtíð. Öll óvissa er slæm fyrir fjárfesta og ekki er hægt að búast við pví að útlendingar vilji festa fé á Íslandi meðan ekki er ljóst hvernig fer með viðamikil atriði sem hafa áhrif á stöðu og rekstur ríkisins um langa framtíð.

Ríkið hefur undirgengist áætlun Alpjóða gjaldeyrissjóðsins. Í henni felst meðal annars mikill samdráttur í ríkisrekstri. Petta er mörgum ráðherrum pvert um geð pó að í mörgum tilvikum sé aðeins verið að vinda ofan af miklum vexti í ríkiskerfinu undir ríkisstjórnum sjálfstæðismanna. Heilagar kýr eru enn margar, til dæmis landbúnaðarstyrkir. Vert væri að nýta tækifærið nú til pess að hætta ýmsu óskynsamlegu eins og flutningi starfsemi af ýmsu tagi út á land pegar pað veldur ópægindum og kostnaðarauka. Atvinnulífið hefur tekið að sér nánast alla hagræðingu frá hruni. Nú er komið að ríkinu að taka til hjá sér.

Í stað pess að eyða dýrmætum tíma í pras um dægurmál, par sem afstaða er aðeins tekin til manna og flokka en ekki málefna, væri eðlilegt að stjórnmálamenn ynnu saman að pví að leysa hin fjölmörgu brýnu viðfangsefni sem fyrir liggja. Eilífar tafir og veikur pingmeirihluti ríkisstjórnarinnar valda pví að stefna er ekki mörkuð og úrlausn brýnna viðfangsefna er slegið á frest. Fyrir tæplega tveimur árum voru tveir pekktir stjórnmálamenn, Steingrímur J. Sigfússon og Davíð Oddsson, sammála um að eðlilegt væri að mynda pjóðstjórn við pær aðstæður sem pá voru. Pörfin er ekki minni nú en pá pó að allir átti sig á pví að slík stjórn yrði aðeins biðleikur meðan ákveðin vandamál væru sett í farveg. Ekkert er jafnhættulegt og 


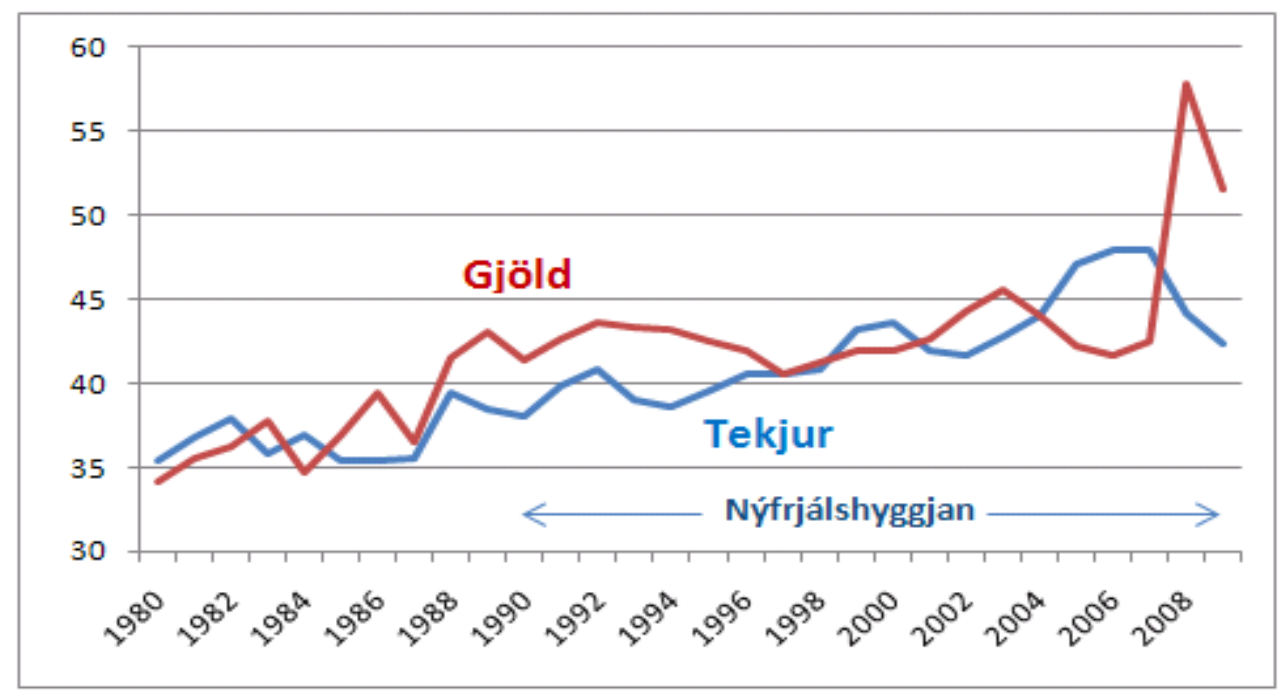

Mynd 5. Tekjur og gjöld hins opinbera sem hlutfall af VLF 1980-2009. Heimild: Hagstofa Íslands.

stefnulaus og sundurpykkur hópur sem á að leiða pjóðina áfram. Aðalatriðið er pó auðvitað að hér starfi samhent stjórn með skynsamlega stefnu sem hún getur hrint í framkvæmd.

\section{Um hvað ætti endurreisnarstjórn að sameinast?}

Раð er óskynsamlegt að vera aðeins á móti hugmyndum annarra en leggja aldrei neitt til sjálfur, líkt og algengt er hjá stjórnmálamönnum nú um stundir. Pess vegna er rétt að setja nú pegar fram stefnumál nýrrar stjórnar:

- Hallalaus fjárlög 2012.

- Markviss stefna um að minnka opinberar skuldir niður fyrir 60\% af VLF á fimm árum.

- Kauphækkanir verði litlar. Núna leiða pær aðeins til atvinnuleysis eða verðbólgu.

- Gjaldeyrishöft afnumin.

- Samningum við Evrópusambandið verði lokið.

- Stefna mörkuð um að hætta notkun krónunnar.

Hallalausum fjárlögum verður að ná með pví að draga úr ríkisrekstri. Pað er skelfilegt að sjá að allir flokkar virðast sameinast um stuðning við óheilbrigt landbúnaðarkerfi, dýrt menntakerfi og óskilvirkt heilbrigðiskerfi. Peir pingmenn sem segjast styðja breytingar á pessum sviðum eru fljótlega kveðnir í kútinn. Forystumenn í öllum flokkum leggjast gegn öllum breytingum sem snerta „heilagar kýr“. Pess vegna verða skattahækkanir alltaf prautalendingin. Hlutur hins opinbera hefur vaxið sem hlutfall af VLF á undanförnum 30 árum, einkum skattheimtan.

Útgjöldin parf ekki að færa mörg ár aftur í tímann til pess að ná jöfnuði. Að vísu eru skuldir miklar og vaxtagjöld pví mjög hár hluti útgjalda. Pau eru líka mjög óviss stærð meðan ekki er vitað um afdrif Icesave-málsins. Miklar vaxtagreiðslur sýna pörfina á pví að minnka skuldabyrði hins opinbera.

Meðan atvinnulífið er enn laskað er ekkert vit í pví að semja um kauphækkanir sem engin innistæða er fyrir. •аð verður að vera forgangsatriði að koma fyrirtækjunum á réttan kjöl og pað eru ekki mörg fyrirtæki sem bera hærri launakostnað í bili. Launahækkanir leiða pá fyrst og fremst til aukins atvinnuleysis eða verðhækkana. 
Á sama tíma er líka forgangsatriði fyrir almenning að línur í skuldamálum skýrist. Par hefur dómur Hæstaréttar um erlend lán mikið vægi og verður til góðs. Pó er enn brýnt að fá svar við mörgum spurningum um lánin, einkum hvaða lán teljist erlend og hver innlend og hvaða vaxtakjör gildi í lánasamningunum.

Gjaldeyrishöftin hafa leitt til pess að tvöfalt gengi myndast og sumir geta nýtt sér pað til pess að kaupa krónur á lægra verði en peir sem fara gegnum hið opinbera kerfi Seðlabankans. Slíkt leiðir alltaf til ósanngirni par sem pað sama gildir ekki um Jón og séra Jón. Forsenda fyrir pví að gjaldeyrishöftin verði afnumin er að erlendar skuldir hins opinbera minnki og að vitað sé hve miklar pær eru.

Skiptar skoðanir eru um Evrópusambandið og satt að segja eru umræður um pað ekki byggðar á nægilegri pekkingu. Innganga í sambandið er forsenda fyrir pví að Íslendingar geti tekið upp aðra mynt með peirri baktryggingu sem nauðsynleg er til pess að stöðugleiki ríki. •að er útilokað að Ísland tapi á pví að ljúka viðræðum við Evrópusambandið og ganga frá aðildarsamningi. Jjóðin hefur alltaf síðasta orðið um pað hvort samningurinn nær fram að ganga eða ekki.

Krónan er áreiðanlega einn helsti skaðvaldurinn í hagkerfi Íslands. Til pess að halda niðri verðbólgu voru vextir hækkaðir, prátt fyrir að pað ráð virki ekki vel pegar aðeins lítill hluti lána er með breytilegum vöxtum. Áhrifin á bæði lán í erlendri mynt og verðtryggð lán voru hverfandi. Með pví að taka upp evru er tryggt að efnahagsáfall af pví tagi sem hér varð leiði ekki til pess að í einu vetfangi hverfi eignir stórs hluta almennings eins og dögg fyrir sólu. Gengisfelling er ekkert annað en eignatilfærsla og olli pví á Íslandi að áratuga sparnaður púsunda manna gufaði upp á einu augabragði. Pess vegna er ekki nóg að binda gengi krónunnar við annan gjaldmiðil eins og til dæmis Danir hafa gert. Peir hafa ekki sýnt pann aga sem slíkt kallar á og gengi dönsku krónunnar er svo hátt að mjög erfitt getur reynst að viðhalda samkeppnishæfni pjóðarinnar í alpjóðaviðskiptum.

Upptaka evru pýðir hins vegar alls ekki að par með purfi ekki lengur að sýna aga við stjórn efnahagsmála. Pvert á móti sýnir vandi Grikkja að með pví að beita blekkingum geta menn komist fram hjá reglum tímabundið en efnahagslögmálin gilda eftir sem áður.

\section{Hvað nú?}

Eftir hrunið var pjóðin í fyrstu slegin, agndofa og miður sín. Í sálfræðinni eru til viðmið um hvernig fólk hegðar sér eftir áfall. Sorg, afneitun og reiði eru áfangar á peirri leið að sætta sig við orðinn hlut. Enginn getur álasað peim sem að ósekju urðu fyrir barðinu á kreppunni miklu, peim sem trúað höfðu fagurgala um að allt væri í himnalagi og að bestu synir pjóðarinnar hefðu leitt hana til velsældar. Рó að einhverjir hafi haft uppi varnaðarorð gat engum dottið í hug hvað í vændum væri.

Vandinn er hins vegar ekki endilega að saklaus fórnarlömb reiðist eða vilji ekki horfast í augu við hvað gerst hefur. Miklu fremur er ástæða til pess að hafa áhyggjur af pví pegar peir sem leiða pjóðina í eiginlegri eða óeiginlegri merkingu vaða fram með ómálefnalegum hætti og dreifa ósannindum, tortryggni og hatri pegar pörf er á heiðarleika, sátt og samstöðu. Sagt hefur verið að vandi samfélaga felist ekki í pví að slæmir menn geri vonda hluti. Vandinn felst í pví að gott fólk situr hjá og lætur illsku, reiði og lygi yfir sig ganga. Alltof lengi var pjóðfélagið í fjötrum pöggunar. Annars vegar vegna pess að fjölmiðlar vildu ekki sjá pað sem amaði að og hins vegar vegna offors stjórnmálamanna sem einir póttust vita og mega vita.

Eftir hrun sögðust allir vilja nýja tíma. Nýir tímar hafa nú runnið upp og eru verri en peir sem fyrir voru. Umræða í pjóðfélaginu er mikil en rökræða er lítil. Fylkingar berjast af 
heift og almenningur veit ekki hvaðan á sig stendur veðrið. Stjórnmálamenn og einkum foringjar flokkanna hafa ekki verið til fyrirmyndar í umræðunni. Forystumenn í atvinnulífinu hafa ekki tekið forystu í pjóðlífinu. Skynsamt fólk hrökklast frá umræðunni og gasprarar taka frumkvæðið. Einmitt núna er nauðsynlegt að snúa af pessari ógæfubraut og snúa pjóðfélagsumræðunni aftur inn á vitrænar slóðir. Stefnuleysið sem ríkt hefur frá hruninu hefur pegar kostað miklar tafir á endurreisninni. Verði pegar snúið aftur frá höftum og miðstýringu og á braut frjálsræðis dregst Ísland sífellt meira aftur úr nágrannapjóðum á næstu árum og áratugum.

Engin leið er að pjóðin komist nokkru sinni út úr kreppunni nema atvinnulífið nái sér á strik. Með lokuðu hagkerfi, vanmáttugum gjaldmiðli og háum vöxtum búa íslensk fyrirtæki við mun lakari aðstæður en pau fyrirtæki sem pau keppa við á erlendum vettvangi. Рað er ekki tilviljun að sum af stærstu fyrirtækjum landsins eru um pessar mundir að færa sig um set. Össur hefur nú pegar fært sig af íslenska hlutabréfamarkaðinum og önnur stórfyrirtæki hafa fært aðalskrifstofur sínar til útlanda. Byggðastefnan snýst ekki lengur um að halda byggð á Raufarhöfn heldur á Íslandi. •að gerist ekki nema hér séu sterk fyrirtæki í stöðugu og hagstæðu rekstrarumhverfi. 
46 Tímarit um viðskipti og efnahagsmál 